\title{
Effect of Training Intervention on Knowledge and Attitude towards Giant Freshwater Prawn Rearing among Students of Rehabilitation Institute in Malaysia
}

\author{
Nur Aidya Hanum Aizam ${ }^{1,2}$, Mhd Ikhwanuddin Abdullah², Siti Nur'afifah Jaafar', \\ Muhammad Razmee Abd Razak ${ }^{4}$, Mohd Izuddin Mashkor ${ }^{4}$, Aidilla Mubarak ${ }^{2,3, *}$ \\ ${ }^{1}$ Faculty of Ocean Engineering Technology and Informatics, Universiti Malaysia Terengganu, 21030 Kuala Nerus, Malaysia \\ ${ }^{2}$ Institute of Tropical Aquaculture and Fisheries, Universiti Malaysia Terengganu, 21030 Kuala Nerus, Malaysia \\ ${ }^{3}$ Faculty of Fisheries and Food Science, Universiti Malaysia Terengganu, 21030 Kuala Nerus, Malaysia \\ ${ }^{4}$ Sekolah Tunas Bakti Sungai Besi, 57100 Kuala Lumpur, Malaysia
}

Received February 18, 2021; Revised April 12, 2021; Accepted July 5, 2021

\section{Cite This Paper in the following Citation Styles}

(a): [1] Nur Aidya Hanum Aizam, Mhd Ikhwanuddin Abdullah, Siti Nur'afifah Jaafar, Muhammad Razmee Abd Razak, Mohd Izuddin Mashkor, Aidilla Mubarak, "Effect of Training Intervention on Knowledge and Attitude towards Giant Freshwater Prawn Rearing among Students of Rehabilitation Institute in Malaysia," Universal Journal of Agricultural Research, Vol. 9, No. 4, pp. 111 - 118, 2021. DOI: 10.13189/ujar.2021.090402.

(b): Nur Aidya Hanum Aizam, Mhd Ikhwanuddin Abdullah, Siti Nur'afifah Jaafar, Muhammad Razmee Abd Razak, Mohd Izuddin Mashkor, Aidilla Mubarak (2021). Effect of Training Intervention on Knowledge and Attitude towards Giant Freshwater Prawn Rearing among Students of Rehabilitation Institute in Malaysia. Universal Journal of Agricultural Research, 9(4), 111 - 118. DOI: 10.13189/ujar.2021.090402.

Copyright $\bigcirc 2021$ by authors, all rights reserved. Authors agree that this article remains permanently open access under the terms of the Creative Commons Attribution License 4.0 International License

\begin{abstract}
Aquaculture activity can potentially help in rehabilitation. The purpose of this study was to explore the effect of training intervention on knowledge and attitude towards giant freshwater prawn rearing in a rehabilitation institute in Malaysia. The program comprised of knowledge transfer on basic techniques of rearing and feed formulation to the students. Effect of the program was evaluated using a pre- and post-interventions design as well as interview. Seventeen trainees from the rehabilitation institute were requested to respond to a 31 items questionnaire. Principal, staff in charge, counsellor and participating students of the institute were interviewed to obtain feedback on the intervention program. Following implementation of the training intervention, there was a significant increase $(\mathrm{p}<0.05)$ in the knowledge with most questions acquired correct answers from the students. A positive attitude towards rearing activity was maintained from pre- to post-intervention showing a sustained interest in this activity among the participants. The conducted interviews also indicated encouraging feedback from the intervention. Positive output from this study indicated great potential of this training to introduce giant freshwater
\end{abstract}

prawn rearing activity as an additional activity towards rehabilitation of students in a rehabilitation institute. This preliminary program showed promising outcome that could be continued for other students in such institute.

Keywords Aquaculture, Giant Freshwater Prawn, Knowledge Transfer, Rehabilitation Institute, Knowledge, Attitude

\section{Introduction}

Aquaculture is defined as production of aquatic plants or animals in a controlled or semi-controlled environment. It is one of the most important sectors worldwide in providing crucial dietary source of protein, lipid, minerals and vitamins to human population (Tidwell and Bright, 2018). Due to growing demand for high quality protein from seafood but decreasing catch from the wild, aquaculture has been largely suggested as an alternative. In addition to ensuring food security, aquaculture has the 
potential for providing socio-economic benefits to the community (Kutty, 2005).

Although Malaysia pioneered the breeding of giant freshwater prawn (Macrobrachium rosenbergii) in late 1950's, the production of this cultured species showed a vast decline in 2006 and simultaneously expanded in other Asia countries including Thailand, China and India (Banu and Christianus, 2016). The production has then showed inconsistent increase in Malaysia, and culturing of fish such as tilapia and eel was reported to be higher despite the huge demand and the economic value of giant freshwater prawn (Banu and Christianus, 2016).

Giant freshwater prawn is therefore among the commercial aquaculture species that has been prioritized by the Department of Fisheries in this country (Anon, 2012), due to the prospect of contributing to the economy. The production of giant freshwater prawn by small and large-scale farmers is supported by various government initiatives towards sustainable food production that meets the demand both locally and internationally.

Malaysia has diverse custodial institutions which target at rehabilitation of children in conflict with the law, including low security facilities under the administration of Department of Social Welfare Malaysia, and also more secure rehabilitative schools and correctional centres under the Malaysian Prison Department (Abd Razak, 2016). Sekolah Tunas Bakti is a gazetted school for education, training and detention of children which was established under Section 65 of Children Act 2001, and administered by the Department of Social Welfare (Department of Social Welfare, 2020). The primary function of this institute is to provide social rehabilitation for children in conflict with the law as an effort to help them reintegrate into the society.

Various activities are performed in rehabilitation institutes including Sekolah Tunas Bakti Sg. Besi as an effort to prepare the offenders to return to the community after serving the term as per court's order. Activities comprised of academic, vocational, co-curriculum, spiritual, as well as guidance and counseling. These activities often focus on altering life paths of the juvenile offenders and improving their chances to develop as productive citizens. The success of effective rehabilitation programs would partly ensure public safety by the reduction of further criminal behavior or recidivism (Lipsey et al., 2010).

According to Yahaya et al. (2004), academic and co-curricular activities were reported to be more effective in comparison to vocational, spiritual, guidance and counselling activities in Sekolah Tunas Bakti Sg. Besi. Rearing of aqua species involves cognitive elements that have potential as a rehabilitation approach for the students, but has not been implemented in any rehabilitation institute in Malaysia. Rearing activity can expose students to good and humane techniques of animal care and such exposure may promote the development of empathy and to take perspective of others (Maruyama, 2010). This can potentially help them to receive better chance of having successful interactions in the society. Performing the rearing activity in groups also provided them the ability to interact with peers, and such participation in group activities have been reported to be important for joy that is vital in positive recovery (Yusoff et al., 2020). In addition, aquaculture activity provides skill that can be a useful preparation for a potential source of income. However, successful aquaculture activity requires basic knowledge of proper rearing techniques. According to You et al. (2006), knowledge transfer is an important aspect of knowledge management that is effective to increase knowledge ability and competency of an organization. Academia is encouraged to transfer expertise to a community in order to ensure the usefulness of academic research to societal wellbeing (Gill, 2019). In line with the encouragement by the Department of Fisheries for expanding giant freshwater prawn culturing activity in Malaysia (Anon, 2012), it is useful to introduce training for such activity to Sekolah Tunas Bakti Sg. Besi. Knowledge transfer on the techniques and the experiences in rearing of giant freshwater prawn is vital to ensure competency of the students in successfully carrying out the rearing activity.

This project therefore aimed at investigating the effect of training intervention related to the rearing of giant freshwater prawn in improving knowledge and attitude towards this aquaculture activity among students of Sekolah Tunas Bakti Sg. Besi. This study's hypothesis was the students would have improved knowledge and sustained positive attitude towards the activity following the intervention.

\section{Methodology}

\subsection{Research Subjects}

Training intervention included 3 main parts; visit to the hatchery in Universiti Malaysia Terengganu, transfer of knowledge by the experts in giant freshwater prawn, and practical-based training that included setting up of the rearing site and the rearing activity that took up to 12 weeks.

\subsection{Training Intervention on Rearing Techniques of Giant Freshwater Prawn}

Training intervention included 3 main parts; visit to the hatchery in Universiti Malaysia Terengganu, transfer of knowledge by experts in giant freshwater prawn and practical-based training that includes setting up of rearing site and the rearing activity that takes up to 12 weeks.

\section{a) Visit to hatchery}

The intervention began with the students' visit to the hatchery of Institute of Tropical Aquaculture, Universiti 
Malaysia Terengganu. The visit aimed at exposing the students to the good practice on rearing giant freshwater prawn. Basic techniques on how the feeding was conducted as well as maintaining a healthy environment were briefly introduced, explained and demonstrated. The visit was concluded with experience sharing session by one of the giant freshwater prawn entrepreneur and ended with Question and Answer session.

\section{b) Knowledge Transfer}

Lectures were provided by 3 researchers on the basic techniques of rearing. These lectures included introduction on physiology and behaviour of giant freshwater prawn, information on the tools required for the rearing activity, the condition of water and the environmental factors that affect a successful rearing. The importance of feed formulation for the species was also introduced. The knowledge shared in this session was implemented during the rearing activity carried out by the students.

\section{c) Practical-Based Training}

Practical-based training included setting up the rearing site in Sekolah Tunas Bakti Sg. Besi. Students were monitored and advised by the researchers throughout the preparation. For the rearing activity, 5000 giant freshwater prawn post-larvae were stocked into 6 different tanks and reared for 8 weeks. The duration was determined for the post-larvae to be fully transformed into juvenile and needed to be transferred to a natural pond. Throughout the duration, students were expected to feed the cultured prawn, monitored the water condition and maintained a healthy environment. All activities were conducted by the participating students of Sekolah Tunas Bakti Sg. Besi.

\subsection{Instrumentation and Data Collection of Knowledge and Attitude Assessment}

Survey by mean of questionnaire was conducted a week before the training of giant freshwater prawn rearing began and right after the program started.

The survey questionnaire comprised of 6 questions regarding demographic profiles which consisted of age, ethnicity, religion, state of origin, the highest education level attained and experience in giant freshwater prawn rearing activity. 18 questions about knowledge on giant freshwater prawn rearing were asked in section B, using categorical scale. Questions 1 to 11 required the respondents to indicate their responses for the options; 'yes', 'not sure' and 'no'. The remaining questions in this section tested the respondents to seek for the correct answers. Each correct answer would contribute to ' 1 ' score and ' 0 ' for wrong answers. The final section in the questionnaire measured students' attitudes towards giant freshwater prawn rearing using 5-point Likert scale.

Questions were developed and established for content validity from the expert in the field and underwent a pilot study before the final version was distributed to the research subjects.

Normality test was conducted for the data of knowledge and attitude before and after the intervention of the giant freshwater prawn rearing training. Both knowledge and attitude data before the intervention were normally distributed i.e. $\mathrm{p}=0.519$ and $\mathrm{p}=0.207$, respectively. Meanwhile, data for similar variables were not normally distributed after the intervention; knowledge $(\mathrm{p}=0.026)$ and attitudes $(p=0.042)$. The data was then subjected to Wilcoxon Signed Rank Test to compare students' knowledge and attitudes towards giant freshwater prawn rearing, pre- and post-interventions. Data analyses were performed using Statistical Package for the Social Sciences (SPSS) for Windows version 20.0.

Face to face interviews were conducted with the school's principal, staff in charge of prawn rearing, counsellor and participated students. Content analysis was used to extract the respondents' feedback on the intervention program which might support the findings of the survey.

\section{Results}

\subsection{Respondents' Profiles}

A total of 17 Malay Muslim male students from Sekolah Tunas Bakti Sg. Besi participated in this study. Table 1 shows a summary of demographic profile of the respondents. Data shown in the table exhibit the majority of participants aged between 16-18 years old (88.2\%). The highest educational level attained for most respondents is at lower secondary form (41.2\%). Most of them have no experience on giant freshwater prawn rearing (82.4\%). This training program is anticipated to expose them to knowledge and practical skills of giant freshwater prawn rearing.

\subsection{Students' Knowledge on Giant Freshwater Prawn Rearing}

The frequency and the percentage of respondents' answering correctly for each knowledge related to item for the pre- and post-trainings questionnaire is presented in Table 2. There is an increasing number of participants who answered correctly for all questions. A drastic increase of percentage was recorded for questions no. 3, 6, 8, 10, 12, 15, 16 and 17. These questions were related to general knowledge of freshwater prawns, feeds and nutrients as well as the rearing protocols i.e. tools required. This increment could be due to the ability of participants to grasp the input from the theory and the practical classes given. Perhaps, freshwater rearing techniques which have been demonstrated somehow had instil interest to the participants leading to better understanding of the topic. Despite that, only a total of 8, 9 and 4 respondents answered correctly to Questions 4, 5 and 9 respectively 
even after the training session. Questions 4 and 5 were related to the prawn feeds while Question 9 was about suitable water $\mathrm{pH}$ level for freshwater prawn rearing. These questions required them to understand about freshwater prawn ecosystem. Perhaps, more elaboration on this topic could better comprehend them.

Table 1. Summary of demographic profile

\begin{tabular}{ccc}
\hline Demographic Profile & & Frequency (Percentage) \\
\hline Age & $13-15$ years old & $2(11.8)$ \\
& $16-18$ years old & $15(88.2)$ \\
\hline \multirow{2}{*}{ State of origin } & Selangor & $3(17.6)$ \\
& Johor & $4(23.5)$ \\
& Pahang & $6(35.3)$ \\
& Kelantan & $2(11.8)$ \\
& Terengganu & $1(5.9)$ \\
Highest Education Level Attained & Sabah & $1(5.9)$ \\
\hline & Never attended formal education & $3(17.6)$ \\
& Primary school & $4(23.5)$ \\
Experience in freshwater prawn & (Standard 4 -6) & $7(41.2)$ \\
rearing & Lower secondary school (Form 1-3) & $3(17.6)$ \\
\hline & Higher secondary School (Form 4-5) & $14(82.4)$ \\
& & $2(11.8)$ \\
\end{tabular}

Table 2. Frequency and percentage of correct responses to knowledge in giant freshwater prawn rearing pre- and post-training

\begin{tabular}{|c|c|c|c|c|}
\hline \multirow[b]{2}{*}{ No. } & \multirow[b]{2}{*}{ Respondents' knowledge towards giant freshwater prawn rearing } & \multirow{2}{*}{$\begin{array}{l}\text { Required } \\
\text { response }\end{array}$} & \multirow{2}{*}{$\begin{array}{c}\text { Pre-training } \\
\begin{array}{c}\text { Frequency } \\
\text { (Percentage) }\end{array}\end{array}$} & \multirow{2}{*}{$\begin{array}{c}\text { Post-training } \\
\begin{array}{c}\text { Frequency } \\
\text { (Percentage) }\end{array}\end{array}$} \\
\hline & & & & \\
\hline 1 & Are giant freshwater prawns raised in fresh water? & Yes & $10(58.8)$ & $16(94.1)$ \\
\hline 2 & Do giant freshwater prawns like dark environments? & Yes & $12(70.6)$ & $15(88.2)$ \\
\hline 3 & Is the size of the female giant freshwater prawn bigger than the male? & No & $1(5.9)$ & $12(70.6)$ \\
\hline 4 & Is the floating pellet suitable to be made as giant freshwater prawn feed? & No & $1(5.9)$ & $8(47.1)$ \\
\hline 5 & Can plants be used as ingredients in giant freshwater prawn feed? & Yes & $8(47.1)$ & $9(52.9)$ \\
\hline 6 & Is protein important in giant freshwater prawn nutrition? & Yes & $9(52.9)$ & $16(94.1)$ \\
\hline 7 & $\begin{array}{c}\text { Can mathematics be used in the manufacturing process of giant } \\
\text { freshwater prawn feed? }\end{array}$ & Yes & $13(76.5)$ & $15(88.2)$ \\
\hline 8 & Is tap water fully used for giant freshwater prawn rearing in the tank? & No & $9(52.9)$ & $16(94.1)$ \\
\hline 9 & $\begin{array}{l}\text { Does the water in the tank need to be changed if the water is in neutral } \\
\text { conditions ( } \mathrm{pH} 6.5-8.5)\end{array}$ & No & $0(0)$ & $4(23.5)$ \\
\hline 10 & $\begin{array}{l}\text { Are ventilation pumps, water and tanks the basic tools used for giant } \\
\text { freshwater prawn rearing? }\end{array}$ & Yes & $9(52.9)$ & $16(94.1)$ \\
\hline 11 & $\begin{array}{c}\text { Do giant freshwater prawn larvae require nursing for } 40 \text { days in the tank } \\
\text { before being transferred to the pond? }\end{array}$ & Yes & $12(70.6)$ & $14(82.4)$ \\
\hline 12 & How many stages are there in giant freshwater prawn life cycle? & 4 & $5(29.4)$ & $12(70.6)$ \\
\hline 13 & $\begin{array}{l}\text { What is the appropriate water temperature for giant freshwater prawn } \\
\text { rearing? }\end{array}$ & $27^{\circ} \mathrm{C}-30^{\circ} \mathrm{C}$ & $10(58.8)$ & $15(88.2)$ \\
\hline 14 & $\begin{array}{l}\text { Which is the WRONG answer to the function of netting in the giant } \\
\text { freshwater prawn tank? }\end{array}$ & $\begin{array}{l}\text { A place for doing } \\
\text { revision }\end{array}$ & $13(76.5)$ & $14(82.4)$ \\
\hline 15 & $\begin{array}{l}\text { How many times should the feed be given to giant freshwater prawn } \\
\text { daily? }\end{array}$ & 2 times & $7(41.2)$ & $13(76.5)$ \\
\hline 16 & $\begin{array}{c}\text { At what age can giant freshwater prawn be given feed in the form of } \\
\text { pellets? }\end{array}$ & More than 30 days & $3(17.6)$ & $13(76.5)$ \\
\hline 17 & Which nutrients should NOT be present in giant freshwater prawn food? & Water & $3(17.6)$ & $12(70.6)$ \\
\hline 18 & $\begin{array}{c}\text { Why is it necessary to have water ventilation for giant freshwater prawn } \\
\text { rearing in the tank? }\end{array}$ & $\begin{array}{l}\text { To gain sufficient } \\
\text { oxygen in the water }\end{array}$ & $12(70.6)$ & $15(88.2)$ \\
\hline
\end{tabular}




\subsection{Student's Attitude towards Giant Freshwater Prawn Rearing Activities}

Students were asked to express their attitudes towards giant freshwater prawn rearing activity using a 5- point Likert scale ( 1 = strongly disagree, $2=$ disagree, $3=$ not sure, 4 = agree and 5 = strongly agree). Median/mean score and standard deviation/mean rank of respondents' attitudes towards giant freshwater prawn rearing from pre- and post-trainings were obtained and reported in Table 3. Normality distribution test indicated the data of attitudes before training was normally distributed while the data for similar variable after the training was found non-normal. Thus, mean score and standard deviation were reported for the pre-intervention data and median score and mean rank were reported for the post-intervention data.

Based on the descriptive data, students generally have positive attitudes towards giant freshwater prawn rearing before (Mean= 4.12, S.D. $=0.94$ ) and after (Median= 4.54, $I Q R=1.17)$ the training. This is possibly because such activity was fun, practical-based and exposed students to soft skill other than formal school learning. The positive attitudes instilled in the involved students were found to increase slightly after the training.

\subsection{Comparison of Respondents' Knowledge Score and Attitudes towards Giant Freshwater Prawn Rearing Before and After Training}

Table 4 shows significant difference in the respondents' knowledge on prawn rearing scores for pre- and post-trainings $(z=-3.46, p<0.05)$. It is possible because the respondents had no formal or informal training regarding prawn rearing before the program. In contrast to knowledge, respondents' attitudes towards giant freshwater prawn rearing before and after the intervention showed no significant difference. Considering the positive attitude prior training, the insignificant difference basically indicated the positive attitude towards the rearing activity was sustained until after the training was delivered.

Table 3. Descriptive statistics of respondents' attitudes towards prawn rearing activities

\begin{tabular}{|c|c|c|c|}
\hline No. & Respondents' attitude towards prawn rearing & $\begin{array}{c}\text { Pre } \\
\text { Intervention } \\
\text { Mean } \\
\text { (Standard } \\
\text { deviation) } \\
\end{array}$ & $\begin{array}{c}\text { Post } \\
\text { Intervention } \\
\text { Median } \\
\text { (Interquartile } \\
\text { Range) } \\
\end{array}$ \\
\hline 1 & I feel that giant freshwater prawn rearing can be a source income. & $4.59(0.80)$ & $5.00(1)$ \\
\hline 2 & I feel that giant freshwater prawn rearing is an easy activity. & $3.53(0.80)$ & $4.00(1)$ \\
\hline 3 & I feel that giant freshwater prawn rearing activity can help me become discipline. & $4.12(0.70)$ & $4.00(1)$ \\
\hline 4 & I feel that rearing activity can increase feelings of affection for other living things. & $4.24(0.83)$ & $4.00(1)$ \\
\hline 5 & I feel that giant freshwater prawn rearing can help in self-rehabilitation. & $3.82(0.95)$ & $4.00(1)$ \\
\hline 6 & I am interested in giant freshwater prawn rearing activities. & $4.53(0.80)$ & $5.00(2)$ \\
\hline 7 & I am interested in learning more about giant freshwater prawn rearing methods. & $4.41(0.94)$ & $5.00(1)$ \\
\hline 8 & $\begin{array}{l}\text { I am interested in the use of plant waste (e.g. fruit peels and seeds) in giant freshwater } \\
\text { prawn feed. }\end{array}$ & $3.59(1.37)$ & $4.00(1.25)$ \\
\hline 9 & I am interested in becoming a giant freshwater prawn farmer. & $4.35(0.70)$ & $5.00(2)$ \\
\hline 10 & I am interested in the use of mathematics in reducing price of giant freshwater prawn feed. & $4.06(1.09)$ & $4.00(1)$ \\
\hline 11 & I look forward to carrying out giant freshwater prawn rearing activities every day. & $4.06(1.30)$ & $5.00(1)$ \\
\hline 12 & I feel more useful with involvement in the giant freshwater prawn rearing activities. & $4.24(0.90)$ & $5.00(1)$ \\
\hline \multirow[t]{2}{*}{13} & I am able to recognize my own abilities through giant freshwater prawn rearing activities. & $4.06(1.03)$ & $5.00(1)$ \\
\hline & Overall & $4.12(0.94)$ & $4.54(1.17)$ \\
\hline
\end{tabular}

Table 4. Comparison of respondents' knowledge score and attitudes towards prawn rearing before and after the intervention

\begin{tabular}{cccc}
\hline No. & Variables & Mean score/ Median & S.D./ IQR \\
\hline 1 & Knowledge score (pre) & Mean=7.47 & S.D $=2.74$ \\
& Knowledge score (post) & Median=14 & IQR=3 \\
2 & Attitude (pre) & Mean=4.12 & S.D $=0.94$ \\
& Attitude (post) & Median=4.54 & IQR $=1.17$ \\
\hline
\end{tabular}




\subsection{Findings of Interviews}

From the interviews, principal, staff in charge, councellor and participants provided positive feedbacks on the intervention program. The principal pointed out that there were changes in students' behaviour, knowledge and skills with regards to giant freshwater prawn rearing:

Principal

After the students participated in the visit to the hatchery, classes, theory and comprehensible learning, we could see big changes in behaviour, knowledge and skill among the students. This is in line with the objective of our institute which is to restore social functionality of our students. The intervention gave a choice of career to the students, and they obtained new knowledge and skill that would surely involve a renewed behaviour. That's where the rehabilitation comes into the picture.

In addition, the staff in charge in this program and the counselor agreed that the program was successful not only in developing the students' knowledge and skill in giant freshwater prawn rearing but also in improving students' discipline and self-development:

Staff in charge

Transfer of knowledge from Universiti Malaysia Terengganu through this intervention helped the success of rearing giant freshwater prawn in this institute. Various positive impacts were obtained from this intervention. Students gained new knowledge in rearing prawn, as well as feeding at specified times. Additionally, students were able to increase their discipline and to manage their daily activities well.

\section{Counselor}

Transfer of skills in rearing of giant freshwater prawn from Universiti Malaysia Terengganu was a high impact program that aided in self-development of the students involved. It opened their eyes towards the possibility of undergoing a more positive life. The training was an initiative towards restructuring lives of these children that had gone through a less healthy routine as child prior to the rehabilitation.

When the students were asked about their achievement of the intervention program, students spoke about positive feedbacks they gained involving;

Improvement on their attitudes and self-development:

Student 1

This activity trained me to become more discipline and to have more patience.

Student 3

I felt excited to see the prawn growing well. I learned how to work thoroughly to ensure the survival of the prawn.

Student 4

I learned to manage my time well and not to give up with problems that might come. I also learned to be more patient to solve problems in my task.

\section{Student 5}

From this activity, I managed to figure out solutions to the problems I faced throughout the rearing process.

Potential of the freshwater prawn skills to them in the future:

Student 2

I think this activity could be a source of income for me when I am released from this institute.

\section{Student 6}

I'm interested to start up a business on rearing of prawn in the future.

This intervention has provided some if not all, about giant freshwater prawn rearing theoretically and practically. More importantly, it improved students' behaviour and provided alternative learning to students at the rehabilitation institute.

\section{Discussion}

The results from this study revealed that there were improvements in total correct response to questions assessing the knowledge on the prawn rearing from pre- to post-trainings for all questions (Table 2). This indicated that the training program in general could increase the participants' knowledge on the basic rearing technique of giant freshwater prawn, and thereafter their competency to carry out the activity. However, there were a few questions involving technical information on feed and water condition that were answered correctly only by a small number of students even after the training session. The lack of understanding in this aspect reflected the possibility for less efficient care in the rearing practice (Jones et al., 2015).

Problem in feed especially the high price is one of the factors in the downfall of freshwater prawn farming (Hossain et al., 2000). Understanding the impact of feed on the effectiveness of rearing giant freshwater prawn is crucial. Therefore, further explanation and perhaps practical experience are essential to comprehend respondents' understanding. A better grasp of knowledge in giant freshwater prawn rearing can guarantee the prospect of generating income revenue for the students when they return to the community. Nevertheless, in general, most questions were understood well after the training was delivered, which showed the efficacy of the training. Similar observation of improved knowledge after the training intervention was also reported by previous studies in fish breeding and agriculture (Goswami, 2011; Mathiasen et al., 2012; Kalsariya et al., 2015).

Although most students did not have previous experience in such rearing activity (Table 1), positive 
observation in attitude towards giant freshwater prawn rearing was found in pre- and post-trainings in this study (Table 3). It is a good indication that this activity has the potential as an additional task in their rehabilitation program. Having the rearing activity done in groups could have been a factor towards positive attitudes among the students. This was also observed by Shibley $\mathrm{Jr}$ and Zimmaro (2002) where collaborative learning improved students' attitudes towards a course and showed committed performance in the course. Encouragement to participate in group activities in this program can help them to improve interactions with peers and create a healthy social activity that potentially aids the positive recovery (Yusoff et al., 2020). Learning and practicing in a group may help to promote students' cognitive development, interpersonal, social skills and improve their ability in resolving conflicts (Maruyama, 2010) that help them to be a better member of community. Engagement and collaboration with university and industry through this activity also may reduce the likelihood of interpersonal violence and delinquency (Zeldin, 2004).

Rehabilitation is often regarded as unnecessary for individual that breaks the law. However, rehabilitation as opposed to mere punishment helps the reintegration and the development of an individual to become productive citizens after being released (Abd Razak, 2016). Combination of rehabilitation was reported to have higher rate of success in improvement of behaviour due to the consideration on emotional needs of a person (Corleto, 2018). Rehabilitation program that uses animals has been reported to teach individuals to be patient, empathetic, less violent and equipped with new skill for animal care (Britton and Button, 2005; Coreleto, 2018). Although these studies refer to animal-assisted intervention particularly programs that involves care of dogs, it could relate to the possibility of positive developments of the students through rearing of aqua species.

The effectiveness of this training on good aquaculture practice in rearing of giant freshwater prawn among the trained students is yet to be investigated. However, this study can be useful to improve the training program as a tool to equip the students for a prospective field and potentially grow into a productive member of the community.

\section{Conclusion}

Knowledge and attitude of students towards rearing of giant freshwater prawn acquiring training are presented in this study. Knowledge on rearing techniques has significantly enhanced following the training. The attitude of the trained students was positively sustained prior and post-trainings, which is a good indicator of interest and potential for this activity to continue in the centre.

There is a need to investigate the effect of aquaculture training on the practices among the students. This is to ensure the effectiveness and the viability of the training or to suggest any required improvements of the training activities. It is also crucial to explore the effect of such rearing activity on the improvement of behaviour among the students. This will ensure a useful activity that can impart positive remark to the rehabilitation goal of the centre.

\section{Acknowledgements}

The authors thank Centre of Knowledge Transfer and Industrial Network (PPIJI) of Universiti Malaysia Terengganu for the support of Knowledge and Technology Assimilation Grant Scheme 2020 (KTAGS 2020) with vot. 58906.

\section{REFERENCES}

[1] Abd Razak, M. R. (2016). Malaysia Juvenile Justice System. United Nations Asia and Far East Institute (UNAFEI) 164th International Training Course, Tokyo, Japan: Resource Material No. 101: 124-128.

[2] Anon (2012) Annual Fisheries Statistics, 2011. Department of Fisheries, Ministry of Agriculture, Malaysia, 20.

[3] Banu, R. \& Christianus, A. (2016). Giant freshwater prawn Macrobrachium rosenbergii farming: a review on its current status and prospective in Malaysia. Journal of Aquaculture Research and Development, 7: 423.

[4] Britton, D. M., \& Button, A. (2005). Prison pups: Assessing the effects of dog training programs in correctional facilities. Journal of Family Social Work, 9(4): 79-95.

[5] Corleto, D. (2018). Prison rehabilition: the sociological, physiological and psychological effects of animal-assisted interventions. Themis: Research Journal of Justice Studies and Forensic Science, 6(1): 8.

[6] Department of Social Welfare (2020, November 16). Sekolah Tunas Bakti. http://www.jkm.gov.my/

[7] Gill, S. K. (2009). Academia, industry and community collaboration in Malaysia: Strategies and opportunities for the

future.http://unesdoc.unesco.org/images/0018/001821/1821 87e. pdf. Accessed October, 1, 2020.

[8] Goswami, B. (2011). Impact of training on ornamental fish breeding and culture of fish farmers' self help group. Journal of Aquaculture in the Tropics, 26(3/4): 147.

[9] Hossain, M. A., Siddique, M. A. L., \& Miaje, M. A. H. (2000). Development of low-cost feed for culture of giant freshwater prawn (Macrobrachium rosenbergii de Man) in ponds. Bangladesh Journal of Fisheries Research, 4(2): 127-134.

[10] Jones, A. C., Mead, A., Kaiser, M. J., Austen, M. C., Adrian, A. W., Auchterlonie, N. A., Black, K. D., Blow, L. R., Bury, 
C., Brown, J. H. and Burnell, G. M. (2015). Prioritization of knowledge needs for sustainable aquaculture: a national and global perspective. Fish and Fisheries, 16(4): 668-683.

[11] Kalsariya, B. N., Bharad, N. D., \& Jadeja, M. K. (2015). Impact of training programme in terms of gain in knowledge for sustainable agriculture. Gujarat Journal of Extension Education, 26(2): 154-157.

[12] Kutty, M. N. (2005). Towards sustainable freshwater prawn aquaculture-lessons from shrimp farming, with special reference to India. Aquaculture Research, 36(3): 255-263.

[13] Lipsey, M. W., Howell, J. C., Kelly, M. R., Chapman, G., \& Carver, D. (2010). Improving the effectiveness of juvenile justice programs. Washington DC: Center for Juvenile Justice Reform at Georgetown University.

[14] Maruyama, M. (2010). The effects of animals on children's development of perspective-taking abilities. Dissertations and Theses, Paper 159, Portland State University.

[15] Mathiasen, L., Morley, K., Chapman, B., \& Powell, D. (2012). Using a training video to improve agricultural workers' knowledge of on-farm food safety. Journal of Extension, 50(1): 1FEA6.

[16] Shibley Jr, I. A., \& Zimmaro, D. M. (2002). The influence of collaborative learning on student attitudes and performance in an introductory chemistry laboratory. Journal of Chemical Education, 79(6): 745.

[17] Tidwell, J.H. \& Bright, L. A. (2018). Freshwater Aquaculture, Encyclopedia of Ecology, pp. 91-96. doi: 10.1016/b978-0-12-409548-9.10618-9

[18] Yahaya, A., Yow, K. G., \& Abdul, A. H. (2004). The effectiveness of behavioral rehabilitation juvenile programmes in Henry Gurney School and Tunas Bakti School. Thesis, Universiti Utara Malaysia.

[19] You, T. H., Li, F. F., \& Yu, Z. C. (2006, August). A method for evaluating the knowledge transfer ability in organization. In International Conference on Knowledge Science, Engineering and Management, pp. 576-585, Springer, Berlin, Heidelberg.

[20] Yusoff, N., Ibrahim, N., \& Ahmad, N. (2020). Negative life events, resilience and depression among moral rehabilitation centre students' of Sekolah Tunas Bakti in Malaysia. International Journal of Health Sciences and Research, 10(3): $1-10$.

[21]Zeldin, S. (2004). Preventing youth violence through the promotion of community engagement and membership. Journal of Community Psychology, 32(5): 623-641. 